\title{
Revising the Supernatural: Prospero Lambertini's Reconsideration of the Concept of Miracle
}

\author{
Alessandro Laverda \\ Department of Humanistic Studies, University of Naples Federico II, Naples, Italy \\ Email: alelaverda@gmail.com
}

\begin{abstract}
According to Thomas Aquinas, a miracle had to surpass the whole of the created nature, which meant the visible and corporeal, as well as the invisible and incorporeal nature. Prospero Lambertini (1675-1758), the future Pope Benedict XIV, when he was promoter of the faith, noticed that it was impossible to distinguish a cure that occurred beyond the boundaries of incorporeal and invisible nature (the whole nature) from one that exceeded just corporeal and visible nature. The issue was of utmost importance since it risked delegitimizing the whole system of miracle verification. Consequently, Lambertini, in the fourth book of his magnum opus De servorum Dei beatificatione et beatorum canonizatione (On the Beatification of the Servants of God and the Canonization of the Blessed, 1734-1738), developed a new classification of miracles, which included the works of angels, with the aim of solving the problem. Furthermore, to counteract Spinoza's denial of miracles, he claimed that miracles were not contrary to the laws of nature.
\end{abstract}

Prospero Lambertini's (1675-1758) reconsideration of the concept of miracle was not the only attempt at revising the relationship between the natural and the supernatural in early modern Catholicism. It needs to be included in three overlapping areas of discussion. First, the Catholic efforts to maintain the gratuity of the supernatural against the Pelagian or semi-Pelagian attacks, especially during the Baian controversy. ${ }^{1}$ Second, the dispute on the nature of miracles that involved the whole of Europe during the seventeenth and eighteenth century. Finally, the post-Tridentine debate on the definition of miracles among canon lawyers, who had the practical task of finding the best way to assess miracles in canonization trials.

I am grateful to David Gentilcore for the comments on earlier drafts of this essay. Special thanks are also due to the unknown reviewers for their suggestions and to Bailey Poletti for the accurate final editing.

${ }^{1}$ The dispute concerned the theologian Michael Baius's (Michel De Bey, 1513-1589) Protestant-like views on some issues, among which was the relation of nature and grace. See Vittorino Grossi, Baio e Bellarmino interpreti di S. Agostino nelle questioni del soprannaturale (Rome: Studium theologicum Agostinianum, 1968); Henri De Lubac, SJ, Augustinianism and Modern Theology, trans. Lancelot Sheppard (London: Geoffrey Chapman, 1969); and, for a different point of view, Marcel Gielis and Karim Schelkens, "From Driedo to Bellarmine: The Concept of Pure Nature in the 16th Century," Augustiniana 57 (2007): 425-448.

(C) The Author(s), 2021. Published by Cambridge University Press. This is an Open Access article, distributed under the terms of the Creative Commons Attribution licence (https://creativecommons.org/licenses/by/4.0/), which permits unrestricted re-use, distribution, and reproduction in any medium, provided the original work is properly cited. 
Whereas the philosophical issues related to the northern European debate on miracles has been in part already outlined, this paper will restrict the inquiry within Catholicism, and in particular it will focus on the works of Lambertini. ${ }^{2}$ The first two sections will give a few examples of the complexity of the debates on miracles within Scholasticism and canonization treatises, which constitute the cultural scenario in which the work of Lambertini must be placed (sections 1 and 2). In the subsequent sections, I will reconstruct in chronological order Lambertini's attempts to revise the definition of miracle: when he was promoter of the faith (section 3), bishop of Bologna (section 4), and finally pope (section 5). The principal objective of the paper is to reconstruct part of the Catholic debate on miracles to understand how Catholicism responded to the cultural changings of the seventeenth and eighteenth centuries.

\section{Francisco Suarez's Definition of Miracle}

Some attitudes and behavior of early modern Catholics concerning the cultural novelties could be considered ambiguous. For example, they sided against Copernican astronomers who argued for a heliocentric cosmos against the geocentric and anthropocentric universe, and they sided against supporters of Democritus and Epicurus who denied the Aristotelian theory of substance. Nevertheless, they did not completely hinder the spread of mechanical philosophy. According to historian Ugo Baldini, this happened for two reasons. ${ }^{3}$ On the one hand, Catholicism was a compound of different factions: the Thomists, the Scotists (both more or less radical), and a residual faction of Occamists, some of them supporters of mechanical philosophy, with others remaining Aristotelian. For example, the Jesuits, Baldini argues, were, on the one hand, leading mathematicians, but they were Aristotelians on issues of metaphysics. Thus they adopted Tycho Brahe's astronomical system even if it was incompatible with the Aristotelian system of planetary spheres. Moreover, the Jesuit Paolo Casati (1617-1707) was the author of the most extensive treatise on metaphysics in seventeenth-century Italy, the Mechanicorum libri octo (1684). And yet, Casati denies the existence of vacuum and air pressure in this work. ${ }^{4}$ Giovanni Baffetti identifies

\footnotetext{
${ }^{2}$ An intellectual history of the miracle is still lacking. That said, a rare and pioneering contribution is Robert M. Burns, The Great Debate on Miracles (London: Associated University Presses, 1981). While limiting his scrupulous inquiry to Protestant England, Burns recognized the philosophical assumptions behind the debate on miracles. See also Jane Shaw, Miracles in Enlightenment England (New Haven, Conn.: Yale University Press, 2006). In a more specific way, both Lorraine Daston, "Marvelous Facts and Miraculous Evidence in Early Modern Europe," Critical Inquiry 18, no. 1 (Autumn 1991): 93-124; and Peter Harrison, "Miracles, Early Modern Science and Rational Religion," Church History 75, no. 3 (September 2007): 493-510, analyzed the different role miracles have come to play in early modern Europe, from signs to evidences of the true Christian religion. All these works focus on the Protestant and northern European debate. The philosophical implications specific to the Catholic context are analyzed in Peter Dear, "Miracles, Experiments, and the Ordinary Course of Nature," Isis 81, no. 4 (December 1990): 663-683; and Fernando Vidal, "Miracles, Science, and Testimony in Post-Tridentine Saint-Making," Science in Context 20, no. 3 (September 2007): 481-508.

${ }^{3}$ Ugo Baldini, "L'attività scientifica nel primo Settecento," in Storia d'Italia: Annali 3. Scienza e tecnica nella cultura e nella società dal Rinascimento a oggi, ed. Micheli Gianni (Turin: Einaudi, 1980), 513-526.

${ }^{4}$ On Jesuits' scientific work, see Romano Gatto, Tra scienza e immaginazione: le matematiche presso il collegio gesuitico napoletano (1552-1670) (Florence: Olschki, 1994); Ugo Ubaldini, ed., Christoph Clavius e l'attività scientifica dei Gesuiti nell'età di Galileo: atti del convegno internazionale (Chieti 28-30 aprile 1993) (Rome: Bulzoni, 1995); and Antonella Romano, La Contre-Réforme mathématique: constitution et
} 
this apparent contradiction as the peculiarity and the limit of Jesuit rhetoric, which consisted of an attempt to reform Catholicism from within and at the same time to keep it in line with tradition. ${ }^{5}$ Indeed, with the aim of counteracting heresy, the Society of Jesus began to train its members in the new philosophy. By the end of the society's first century of life, 650 new centers had risen all over the world, and the Ratio atque institutio studiorum Societatis Iesu, the official plan for Jesuit education, had been established. The Ratio included a training program on the new science, especially in mathematics, which guaranteed the presence of the society at the center of the heated debates of the century. ${ }^{6}$

The theologian who proposed a resetting of the definition of miracle after the Council of Trent (1545-1563) was a Jesuit: Francisco Suarez (1548-1617). ${ }^{7} \mathrm{He}$ was a Spanish Jesuit who graduated in Salamanca and taught first philosophy and then theology in Spain, Italy, and Portugal. ${ }^{8}$ Though he moved within Thomistic theology, Suarez developed new philosophical and theological doctrines. His knowledge was immense, and his works covered all fields of theology, philosophy, and ethics. $\mathrm{He}$ broke with the tradition of commentaries-on which all medieval Scholasticism, disconnected from the text, was founded-and inaugurated systematic monographs. ${ }^{9}$

Although Suarez did not write a specific treatise on miracles, his concept of miracle can be largely inferred from two works: the De legibus (1612) and the Disputationes de angelis (1620). Suarez discusses his theory of miracle within the framework of "eternal law" (lex aeterna), since this is the law which all creation obeys. He claims that it would

diffusion d'une culture mathématique jésuite à la Renaissance (1540-1640) (Rome: École Française de Rome, 1999). On the spread of experimental science among Catholic orders, see Antonella Barzani, Gli affanni dell'erudizione: Studi ed organizzazione culturale degli ordini religiosi a Venezia tra Sei e Settecento (Venice: Istituto veneto delle scienze, lettere ed arti, 2004); and Federica Favino, "Scienza ed erudizione nei collegi degli ordini religiosi a Roma tra Sei e Settecento" in Religione conflittualità cultura: Il clero regolare nell'Europa di antico regime, ed. Massimo Carlo Giannini (Rome: Bulzoni, 2006), 331-370.

${ }^{5}$ Giovanni Baffetti, Retorica e Scienza. Cultura gesuitica e seicento italiano (Bologna: CLUEB, 1997), 70.

${ }^{6}$ Mario Barbera, La Ratio studiorum e la parte quarta delle Costituzioni della Compagnia di Gesù (Padua: Cedam, 1942); and Gian Paolo Brizzi, ed., La "Ratio studiorum": Modelli culturali e pratiche educative dei Gesuiti in Italia tra Cinque e Seicento (Rome: Bulzoni, 1981). However, the inner history of the society reveals a shift in attitude towards the "new science." For example, in 1611, the Jesuits Odo von Maelconte, Christopher Grienberger, and Cristoforo Clavio approved Galileo's observations on the moon spots, while the Jesuit Mario Bettini was firmly against the theory of the presence of mountains on the moon. Furthermore, Giovanni Luigi Confalonieri professed sympathy for anti-Aristotelian theories on natural philosophy while Giovanni Battista Riccioli (1598-1671) opposed Galileo's theory of movement. See Federica Favino, "Ordini religiosi e scienza moderna," in Il Contributo italiano alla storia del pensiero, ed. Antonio Clericuzio and Saverio Ricci, Enciclopedia Italiana, Appendix VIII (Rome: Istituto Treccani, 2013), 1-8.

${ }^{7}$ Suarez's concept of miracle has not yet been taken into account by historians. The only available investigation is a brief article written by the Jesuit Norbert Brieskorn, "Suárez and the Question of Miracles," Revista Portuguesa de Filosofia 65 (2009): 1315-1318.

${ }^{8}$ Francisco Suarez's bibliography is relatively large. However, while it mainly concerns his works on metaphysics and law (Disputationes metaphysicae and De legibus ac Deo legislatore), Suarez's theological treatises (De gratia and De angelis, for instance) are almost ignored by historians. For an exhaustive bibliography, see Jean-Paul Coujou, Bibliografia suareciana (Pamplona: Servicio de Publicaciones de la Universidad de Navarra, 2010); and, for a constantly updated online bibliography, "Bibliography of works on Francisco Suárez, 1850-present," Sydney Penner, accessed March 1, 2021, http://www.sydneypenner.ca/bib.shtml.

${ }^{9}$ José Pereira, Suarez: Between Scholasticism and Modernity (Milwaukee: Marquette University Press, 2008), 37-65. 
be wrong to separate providence from eternal law, since God is unity and acts according to eternal law through the measure of providence. In response to the main question-Is God breaking the eternal law? - Suarez notes that it can be claimed that God could act through his providence outside of eternal law. For example, if the sun stops its course, then it could be argued that it would be an effect of providence, not of eternal law (which requires that the sun moves continuously). ${ }^{10}$ Suarez claims that if something could be understood as a dispensation from eternal law, as in the case of the of sun that stops its course, it is only due to the obedience to another part of eternal law, such as human prayer. ${ }^{11}$

Although the fact that the sun stands still is not a result of the eternal law as it prescribes the order to be observed in the movements of heavenly bodies-nay, more, although the fact is a dispensation therefrom-nevertheless it is congruous with another precept of the eternal law, whereby God wills that the prayers of those that love Him shall be heard, when they pray in a due manner and for a just cause. $^{12}$

Suarez finally refers to Augustine's well-known definition of miracle as something not contrary to the course of nature but just beyond the knowledge of men. ${ }^{13}$ What is valid for the eternal law is also valid for natural law, which regulates human behavior on earth, since the latter is included in the former. The fact that sometimes it appears to human beings that God is breaking natural law is once again due to our ignorance of the whole of natural law.

This is what can be understood of Suarez's concept of miracle from De legibus. In his treatise Disputationes de angelis (1620), Suarez criticizes Aquinas's definition of miracle as something surpassing the whole of created nature, opting for a looser definition that has also to include the work of angels. Suarez observes a discrepancy between the so-called proper definition of miracle and some events that are commonly assigned as miracles. He suggests including invisible and incorporeal nature in the definition of miracle, which should encompass the work of angels. At the beginning of the section entitled, "Whether angels by assuming bodies, can perform true and miraculous things through them" (Utrum angeli assumentes corpora, per ea possint vera et miraculosa opera efficere), Suarez points out that his argument is only valid if miracles are understood in the broad sense-as something that goes beyond the order of corporeal nature, not beyond the whole of created nature. ${ }^{14}$ He states that if the emphasis is on the limits of the faculty (virtus) of created nature, then angels as created beings would never surpass their own power and so would never be able to perform miracles. On the contrary, if the emphasis is on the boundaries of the usual order of things, angels would be able to perform miracles. ${ }^{15}$ He writes, "Therefore, in an absolute sense the true miracle will be everything which occurs in the world beyond the usual order of nature, or which occurs

\footnotetext{
${ }^{10}$ Francisco Suarez, De legibus, vol. 5 (Paris: Vives, 1856), 96 (3.2.14).

${ }^{11}$ Suarez, De legibus, 96.

${ }^{12}$ Suarez, De legibus, 96. The translation is taken from Francisco Suarez, Selections from Three Works of Francisco Suarez, ed. Thomas Pink, trans. Gwladys L. Williams, Ammi Brown, and John Waldron (Indianapolis: Liberty Fund, 2015), 183.

${ }^{13}$ Suarez, De legibus, 96.

${ }^{14}$ Francisco Suarez, De angelis, vol. 2 (Paris: Vives, 1856), 559 (4.39).

${ }^{15}$ Suarez, De angelis, 560 .
} 
in bodies beyond the whole order of corporeal nature. Thus angels can do many things beyond the whole order of corporeal nature." 16

A second point stressed by Suarez is that not all miracles are the same. Some are nobler than others, either for the effects produced or for the way in which they happen. Nevertheless, all miracles have to exceed the natural order of things-and the natural capacity of matter-or they have to exceed the connatural way in which the effect requires that it happen by itself (quo talis effectus per se fieri postulat). ${ }^{17}$ Whereas a sudden cure from a serious disease, without any help from the art of medicine, might well be considered a miracle, this has no implication on a resurrection, which would be considered without doubt a miracle. These two types correspond to two different degrees of miracles: one beyond corporeal and physical nature, the other beyond the whole of created nature. Consequently, Suarez argues that it is simply wrong to restrict the meaning of miracle exclusively to the overcoming of all nature when there are miracles that surpass only corporeal nature. He deeply explores the nature of the third type of miracle in Aquinas's classification, which occurs when the fact produced surpasses the power of nature according to the way it is produced, like someone immediately cured from fever. ${ }^{18}$

On the contrary, it is commonly believed that angels cannot perform any miracles because matter does not obey their act of will (ad nutum). They cannot do anything by their own will since they are created beings, though spiritual and superior to humans. Only God is capable of creating something ex nihilo, without the means of any secondary causes, and just through an act of will.

When Suarez makes a claim for miracle going beyond corporeal nature, he is not just proposing to expand the capacity of miracle-working to angels. He is also pushing for a new definition of miracle. Beside God's performance ex nihilo, he places angels' performance ex arte. Whether he is aware of it or not, Suarez is adapting the definition of miracle to a new sensibility regarding the relationship of God and nature. In the early modern period, the division between created nature in visible and corporeal nature, on the one hand, and invisible and incorporeal, on the other, became much crisper. The former was the nature detected by human senses; the latter was the nature of occult causes. At the same time, the boundaries between the whole of created nature and the supernatural became much more blurred. Finally, even God began to be seen as an artisan by seventeenth-century natural philosophers-indeed, the greatest artisan.

We will come back to Suarez when I will deal with Lambertini. In the following section, I will present two different proposals made by canon lawyers to rationalize miracles, made necessary by the seventeenth-century legal turn of the canonization

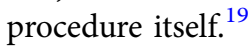

\footnotetext{
${ }^{16}$ Suarez, De angelis: 560: "Erit ergo simpliciter verum miraculum, quidquid fit in mundo praeter consuetum ordinem naturae, vel quod fit in corporibus supra totum ordinem naturae corporeae: angeli autem possunt multa opera facere supra totum ordinem naturae corporeae." My translation, as are all others unless otherwise noted.

${ }^{17}$ Suarez, De angelis, 562-563.

${ }^{18}$ Aquinas distinguished miracles beyond (praeter), against (contra) and above (supra) nature or those which exceed nature according to the substance (quoad substantiam), according to the subject in which they occur (quoad subiectum), and according to the way they happen (quoad modum). See sections 2 and 5.

${ }^{19}$ Simon Ditchfield, "Thinking with Saints: Sanctity and Society in Early Modern World," Critical Inquiry 35, no. 3 (Spring 2009): 552-584.
} 


\section{The Debate on Miracles in Canonization Treatises: Carlo Felice De Matta and Francesco Bordoni}

Between the mid-sixteenth and mid-eighteenth centuries, the need for a useful method of discerning true from false miracles led many canon lawyers to publish treatises on the subject, usually as part of works on canonization. ${ }^{20}$ Due to a set of reforms on the canonization procedure, implemented from the first half of sixteenth century, discussions regarding miracle classification intensified. ${ }^{21}$ The author of the first treatise on canonization was Martino Garati (d. 1453), who wrote his De canonizatione sanctorum to facilitate the canonization of Bernardino da Siena, probably between 1446 and 1448 . A few years later, Troilo Malvezzi (1432-1495) wrote a similar treatise based almost exclusively on Garati's writings, beating his colleague to the claim of publishing the first canonization treatise. ${ }^{22}$ In the sixteenth century, the canon lawyer Giacomo Castellani wrote a third treatise, called Tractatus novus de canonizatione sanctorum, published in 1521. It is a brief treatise; in it, the main elements used to define a miraculous event appear. First, the miracle is considered a fact performed by God exclusively; demons and angels do not perform miracles. Since they could not create something out of nothing (ex nihilo), which is God's prerogative, they could only create something using the potency existing in the matter itself (ex arte). Second, miracles have to exceed the faculties of created nature. This could happen in two ways: according to the fact in itself (quo ad factum) or according to the way in which a fact happens (quo ad modum facti). ${ }^{23}$ This distinction between two kinds of miracles appeared from the earliest treatises on canonization. This classification does not belong to Augustine and precedes the systematization of the concept of miracle made by Aquinas. Rather, it derives from Aquinas's predecessor at the chair of theology in Paris, Alexander of Hales (11851245), who was the first to use available logical tools provided by the rediscovered Aristotle to redefine miracles.

Aquinas in the Summa Theologica defines miracles according to three different degrees. He still classifies them using the power of nature, yet he adds a third class of miracles between the two classes found in Alexander of Hales. The first degree of miracles includes those which exceed nature according to the substance (quantum ad

\footnotetext{
${ }^{20}$ This is a list of the most quoted: Troilo Malvezzi, De canonizatione sanctorum (Bononia: Ugo Rugerio 1487); Giacomo Castellani, Tractatus novus de canonizatione sanctorum (Rome, 1521); Angelo Rocca, De canonizatione sanctorum (Rome: Guilelmum Facciottum, 1601); Paolo Zacchia, "De miraculis," in Quaestiones medico-legales (Amsterdam: Ex Typographejo Joannis Blaev, 1651); Felice Contelori, Tractatus et praxis de canonizatione sanctorum (Lyon: Sumptibus Laurentii Durand, 1634); Fortunato Scacchi, De cultu et veneratione servorum Dei (Rome: Ex Typographia Vitalis Mascardi, 1639); Giacomo Pignatelli, Consultationum canonicarum (Venice: Paulum Balleonium, 1646); Lorenzo Brancati di Lauria, "De miraculis," in Commentaria tertium librum sententiarum Ioannis Duns Scotis, vol. 4 (Rome: Haeredum Corbelletti, 1676); Carlo Felice De Matta, Novissimus de canonizatione sanctorum (Rome: Typis et Sumptibus Nicolai Angeli Tinassij, 1678); Francesco Bordoni, Opus posthumum, consistens in diversis meditationibus, ordine contexto super miraculorum essentiam, \& qualitatem (Parma: Typis Pauli Monti, 1703); Agostino Matteucci, Practica theologico-canonica (Venice: Nicolaum Pezzana, 1722); and Prospero Lambertini, De servorum Dei beatificatione et beatorum canonizatione (Bononia: Formis Longhi Excusoris Archiepiscopalis, 1738).

${ }^{21}$ See Miguel Gotor, I beati del papa: santità, inquisizione e obbedienza in età moderna (Florence: Leo S. Olschki, 2002); Giovanni Papa, Le cause di canonizzazione nel primo periodo della congregazione dei Riti (1588-1634) (Rome: Urbaniana University Press, 2001); and Ditchfield, "Thinking with Saints."

${ }^{22}$ Domenico Maffei, "Il trattato di Martino Garati per la canonizzazione di San Bernardino da Siena," Studi senesi 2 (1988): 580-603.

${ }^{23}$ Castellani, Tractatus novus, n.p.
} 
substantiam facti), such as the sun retroceding its course. The second degree happens when a fact surpasses the power of nature not in relation to the fact produced but to the subject in which it is produced (quantum ad id in quo fit), as in the case of resurrection. The third degree occurs when the fact produced surpasses the power of nature according to the way it is produced (quantum ad modum et ordinem faciendi), like someone immediately cured from fever. ${ }^{24}$ In all three classes of miracles, the paradigm is nature: Aristotle's nature, which is ruled by secondary causes.

After the Council of Trent, Catholic reformers decided to counteract the Protestant teaching of the end of miracles by increasing control over the canonization process and by providing it with a juridical and legislative apparatus. ${ }^{25}$ For the precise identification of the different types of miracles, a classification of miracles shared by the cardinals in charge of judging a canonization cause was required. Aquinas's tripartition of miracles had already been used in the canonization of Saint Leopold III the Pious in 1485. However, between the beginning of the seventeenth century and the first half of the eighteenth century, a range of treatises on canonization procedure were published, each of them providing different inputs on miracle classification. ${ }^{26}$ The reason lay in the fact that the authors belonged to different religious orders, such as the Franciscans or the Society of Jesus. The Franciscans traditionally followed Augustine and the medieval Franciscan doctors, such as Alexander of Hales and Duns Scotus. The Jesuits were a modern order and followed Aquinas, although not in as direct a way as the Dominicans did. Accordingly, some Jesuits either did not accept Aquinas's tripartition of miracles or tried to modify it.

In this section, I will analyze two different cases in which Aquinas's tripartition of miracles was partially or completely rejected. This will help put Lambertini's revision of the classification of miracle, which was not an isolated proposal, in the right light. Indeed, the first author to suggest a new classification of miracle was the bishop Carlo Felice de Matta (1622-1701). His treatise Novissimus de sanctorum canonizatione tractatus was published in 1678 . According to de Matta, the problem lay with the recognition of so-called negative miracles. He subdivided miracles into positive and negative ones. The former occurred when something was added to an initial state, such as the resurrection of a dead man or a recovery from a disease, in which the passage from a state of illness to a state of health was evident. In negative miracles, on the contrary, nothing new was added, and the subject remained in its initial condition, such as when something that should burn in contact with the fire did not or when someone who should have been drowned did not. Whereas positive miracles could be used in a canonization process, since they were perceptible to the senses, de Matta claimed that negative miracles could not be proved by witnesses, since nothing new happened. The only way to proceed towards negative miracles was by argumentation. ${ }^{27}$

De Matta developed a method of identifying miracles that he believed would dispel any doubts. He basically refuted Aquinas's tripartition of miracle and instead suggested a new tripartition based on negation and privation, according to Aristotle's physics. Nature was described by Aristotle in constant motion and mutation (kinesis). This was of four types: according to the place, which was the motion of something from

\footnotetext{
${ }^{24}$ Thomas Aquinas, The Summa Theologica, vol. 1, trans. Fathers of the English Dominican Province (Chicago: Encyclopaedia Britannica, 1952), 545 (1.105.8).

${ }^{25}$ See Ditchfield, "Thinking with Saints."

${ }^{26}$ See Matteucci, Practica theologico-canonica, 165 (3.2.5).

${ }^{27}$ De Matta, Novissimus, 170-171 (3.8.13).
} 
one place to another; according to quantity, which was the growing of a being; according to quality, which was the mutation of color of a thing; and according to substance, which was the birth of a being. Each of these types of kinesis could be described as the passage of matter as substrate from privation of a form to the acquisition of that form. De Matta explained the difference between negation and privation in accordance with this Aristotelian physics. The former consisted of the absence of form or act that the subject should not have naturally; the latter concerned the absence of form or act that the subject naturally should have. For example, blindness in humans was privation, whereas in plants it was negation. Furthermore, privation could be perpetual or temporary: blindness from birth was usually perpetual, whereas a disease could be a temporary state. Accordingly, de Matta divided miracles into three types. A miracle of the first kind was something against negation, such as a talking mule, in which the perfectly natural absence of speech was instead reversed. A miracle of the second kind was something against perpetual privation, such as resurrection, according to which the perpetual absence of life in a dead person was removed. A miracle of the third kind was something against a temporary privation, such as the recovery from an incurable disease, according to which the absence of health-in which the subject was temporarily held-was removed. ${ }^{28}$

De Matta's classification of miracles did not meet with the approval of the Congregation of Rites and was never applied. Agostino Matteucci and Prospero Lambertini criticized de Matta's evaluation of negative miracles as inconsistent. ${ }^{29}$ Although de Matta probably missed the target and focused his effort on a non-existent problem, his theorizing was an example of the various attempts made in the seventeenth century to define a precise means to detect miracles accurately.

The second author I will consider is the Franciscan Francesco Bordoni (1594-1671). From the second half of fifteenth century, two schools of thought had faced one another: one following the via Thomae, the other the via Scoti. ${ }^{30}$ One of the themes of the controversy focused on the relationship between God and nature. On the one hand, Thomas Aquinas believed the relationship between God and nature was analogical. This meant that an attribute we apply to a natural thing could not have the same meaning when it is applied to God because they are ontologically different. Nevertheless, they are similar, since one is applied to the cause and the other to the effect, and each effect is similar to its cause. Hence, their relationship is not univocal, and even not completely equivocal, but rather analogical. On the other hand, John Duns Scotus believed the relationship between God and nature was univocal. He said that we cannot give a similar use of a term - that is to say, a use of a term according to two different but in some way related meanings-if we do not give something that can be uniquely affirmed of the same realities of which the term in question is analogically affirmed. Therefore, the possibility of analogous statements of divine names presupposes, and does not exclude, that there are also concepts that apply unequivocally to God and to creatures. ${ }^{31}$

\footnotetext{
${ }^{28}$ De Matta, Novissimus, 171-173.

${ }^{29}$ Matteucci, Practica theologico-canonica, 195-196 (3.3.36-37); and Lambertini, De servorum Dei beatificatione (1738), 309-311 (4.22.1-4).

${ }^{30}$ See Antonio Poppi, Causalità e infinità nella scuola padovana dal 1480 al 1513 (Padua: Antenore, 1966); and Franco Riva, Analogia e univocità in Tommaso de Vio “Gaetano" (Milan: Vita e pensiero, 1996).

${ }^{31}$ On Thomas Aquinas's analogy of being, see Bernard Montagnes, OP, Doctrine of the Analogy of Being according to Thomas Aquinas, trans. Edward M. Macierowsky (Louvain: Marquette University Press, 2008);
} 
The controversy between Thomists and Scotists is evident in seventeenth-century debates over miracles. Three of the canon lawyers who wrote on canonization were Franciscans. Lorenzo Brancati di Lauria (1612-1693) and Agostino Matteucci (d. 1720) were both Scotists who sought a way of reconciling the two parties, at least regarding the classification of miracles, by accepting Aquinas's tripartition of miracles and the definition of miracle as something against nature. Bordoni, by contrast, was a hardline Scotist. He had taught theology at the university of Bologna since 1621 and was consultor of the local Inquisition tribunal. ${ }^{32}$ Bordoni wrote a treatise on miracles entitled De miraculis, published in 1703, in which he agreed that a miracle was a supernatural event that exceeded the whole order of nature (ordinem totius naturae). ${ }^{33}$

However, Bordoni's identification of some miracles as according to nature differs from contemporary classifications of miracles since he did not base the notion of miracle on the concept of contrariness between the natural and the supernatural. Behind Bordoni stood Duns Scotus, who understood the relationship between the natural and the supernatural not analogically but univocally. For these reasons, Bordoni could not accept an ontological opposition between nature and supernature nor a general definition of miracle as something against nature. He openly quoted Scotus's statement on this issue: "The natural and the supernatural are not distinguished by the nature of something in itself, but for the comparison of the agents." ${ }^{4}$ A miracle is defined by its agent, which is God; whenever something is produced by a secondary cause, it is natural. This meant that it was not possible to distinguish the natural and the supernatural ontologically but only according to the efficient cause that operates on a passive potency. Whenever the active principle that operated on it belonged to the order of the natural things, it was a natural event; whenever it was something out of natural order, it was supernatural. However, it was not enough to identify something as supernatural in which the agent was supernatural; it had also to operate supernaturally. Whenever God operated according to the potency of created beings, he operated naturally; whenever he exceeded their potency, he operated supernaturally. ${ }^{35}$ The emphasis on agents and acts rather than on the opposition between the natural and the supernatural would compromise the usefulness of Bordoni's classification of miracles in canonization trials, although this way of considering the supernatural would not be totally abandoned.

and Ralph McInerny, Aquinas and Analogy (Washington, D.C.: The Catholic University of America Press, 1996). On Duns Scotus's univocity of being, see William E. Mann, "Duns Scotus on Natural and Supernatural Knowledge of God," in The Cambridge Companion to Duns Scotus, ed. Thomas Williams (Cambridge: Cambridge University Press, 2002), 238-262; and Mechthild Dreyer and Mary Beth Ingham, The Philosophical Vision of John Duns Scotus: An Introduction (Washington, D.C.: The Catholic University of America Press, 2004).

${ }^{32}$ Massimiliano Zanot, Francesco Bordoni (1594-1671): teologo, inquisitore, storico (Rome: Editrice Franciscanum, 1999).

${ }^{33}$ Bordoni, Opus posthumum, 7 (1.24-25).

${ }^{34}$ Bordoni, Opus posthumum, 6; and Duns Scotus, Quaestiones quatuor voluminum scripti Oxoniensis super sententias (Venice: Typis Io-Iacobi Hertz, 1680) 227 (4.10.8.9): "naturale et supernaturale non distinguunt naturam alicuius in se ipso, sed per comparatione ad agens."

${ }^{35}$ Duns Scotus, Reportatio Parisiensis, (bk. IV, d. 10, q. 9, n.11): "ens scibile supernaturale non potest fieri nisi ab agente supernaturali et actione supernaturali." Quoted in Juan Alfaro, Lo natural y lo sobrenatural: estudio historico desde Tomas Cajetano (1274-1534) (Madrid: Consejo Superior de investigationes Cientificas, 1952), 51. 
These different attempts at miracle rationalization seem to have met a requirement of the miracle investigation procedure, based on the need for a functional system to identify and classify miracles. It was mostly a discussion internal to the canonization procedure, as we shall also see in the case of Lambertini.

\section{Prospero Lambertini}

Prospero Lambertini was born in Bologna in 1675, where he graduated in theology and law in 1694. Pope Clement XI (1700-1721) nominated him consistorial lawyer in 1700, and he was in charge of promoting the causes of Caterina da Bologna and Pio V, both canonized during Clement's pontificate. In 1708, Lambertini was nominated Promoter of the Faith, a position which he held for twenty years. ${ }^{36}$ The task of the Promoter of the Faith was to supervise the inquiry into the virtues of the candidate for sainthood and the investigation into alleged miracles that occurred after his or her death. He raised critical issues about the reports made by the lawyer promoting the cause and by the medical experts, who had the role of understanding whether a supposed miracle had surpassed the forces of nature or not. In the animadversiones (observations) that Lambertini wrote as Promoter of the Faith, it is possible to find his early approaches to the problem of miracle assessment. The animadversiones consisted of some observations raised by the Promoter of the Faith regarding any impediments on the proceeding of miracle confirmations. In one of these evaluations, Lambertini concludes his report by denying the possibility of miracle cures whenever the disease was curable by spiritual beings. It happened in the novae animadversiones (1726) of Peter Fourier's beatification process. ${ }^{37}$ Here Lambertini, as Promoter of the Faith, after having denied for the second time the miraculous nature of five cures, concludes by saying that none of the cures exceeded the power of angels, since all the alleged miracles were just sudden and instantaneous cures, as a result of which they could not be classified as miracles. He refers to Angelo Rocca's De canonizatione sanctorum (1601), in which the work of medical doctors is compared to the work of angels. ${ }^{38}$ According to Lambertini, and in line with Christian orthodoxy, one of the differences between human beings and spiritual beings is knowledge. Angels know much more than humans do, and, accordingly, they are more skilled in many arts. This happens in medical knowledge, too: "Good and bad

\footnotetext{
${ }^{36}$ For an overview on his life and works, see Louis Antoine Caraccioli, Vita del papa Benedetto XIV Prospero Lambertini con note istruttive (Venice: Simone Occhi, 1783); Ludwig von Pastor, The History of the Popes, vol. 35, Benedict XIV (1740-1758) (London: Routledge Kegan Paul, 1949); Marco Cecchelli, ed., Benedetto XIV (Prospero Lambertini): Convegno internazionale di studi storici, Cento 6-9 dicembre 1979, vols. 2 (Cento: Centro studi Girolamo Baruffaldi, 1982); Andrea Zanotti, ed., Pastore della sua città, pontefice della cristianità (Argelato: Minerva, 2004); Maria Antonietta de Angelis, Prospero Lambertini: un profilo attraverso le lettere (Città del Vaticano: Archivio segreto Vaticano, 2008); Gaetano Greco, Benedetto XIV (Rome: Salerno Editrice, 2011); Maria Teresa Fattori, ed., Le fatiche di Benedetto XIV: Origine ed evoluzione dei trattati di Prospero Lambertini (1675-1758) (Rome: Storia e Letteratura, 2011); Maria Teresa Fattori, Storia, medicina e diritto nei trattati di Prospero Lambertini (Rome: Storia e Letteratura, 2013); and Rebecca Messbarger, John Gavitt Philip, and Christopher M. S. Johns, ed., Benedict XIV and the Enlightenment: Art, Science, and Spirituality (Toronto: University of Toronto Press, 2016).

${ }^{37}$ Peter Fourier (1565-1640) was a French priest who reformed the Canonici Regolari di Sant'Agostino based in Loren and founded the Canonichesse della Congregazione di Nostra Signora. He was beatified in 1730 and canonized in 1897.

${ }^{38}$ Rocca, De canonizatione sanctorum, 55-56.
} 
angels, who are deeply skilled in the exact knowledge [scientia] of all things, and who are deeply informed of the causes of diseases, ordered the matter subjected to them easily and quickly to produce the recovery, after having removed the hindrances, which go unknown to physicians or which they cannot remove." 39

According to Thomas Aquinas, a miracle had to surpass the whole of the created nature, which means the visible and corporeal as well as the invisible and incorporeal nature, occupied by good and bad angels. ${ }^{40}$ The supposed miracles under examination were merely sudden and instantaneous cures that angels could also perform. As a result, Lambertini was faced with a dilemma: were sudden recoveries from long-term diseases to be considered miracles? If they were not, then a huge number of previous miracle cures would have to be nullified; but if they were, then it would have to be affirmed that angels could also produce miracles.

In 1726, Lambertini had already had eighteen years' experience as Promoter of the Faith, and he probably tried to gauge the reactions and consequences if the first position was applied. In fact, the consistorial lawyer promoting the cause, Carlo Alberto Guidobono Cavalchini (1683-1774), who had the task of replying to Lambertini's observations, included in his response a responsio theologica focused exclusively on the issue raised by the Promoter of the Faith. It is a long essay divided into two sections. The first part deals with the question of whether good and bad angels could produce miracles. The second part focuses on whether diseases that nature and the art of medicine could cure after a long period of time, if suddenly cured, could be classified as miracles. From the beginning, Guidobono Cavalchini distinguishes between the proper definition of miracle as something exceeding the order of the whole of nature and a loose definition of miracle as something exceeding the order of corporeal nature. Angels could produce something that surpassed the faculty of human beings; however, this could not be considered a true miracle. According to Guidobono Cavalchini, true miracles are only those performed by God. Firstly, he refers to Aquinas's Summa Theologica (p. 1, q. 110, art. 4), which stated that angels could not perform miracles for their own virtues but only as an instrument of God's virtues. ${ }^{41}$ Secondly, Guidobono Cavalchini refers to the institutional authority of the Congregation of Rites, which had always approved sudden healings as miracles. ${ }^{42}$ Thus he claims that angels could not perform true miracles.

In the second section of the essay, Guidobono Cavalchini tries to resolve the issue of how to differentiate between a sudden cure worked by an angel (beyond the corporeal and visible nature) from one made by God (beyond the spiritual and invisible nature). He does so by making use of the following expedient: whether in a disease that was

\footnotetext{
${ }^{39}$ Prospero Lambertini, Sacra Rituum Congregatio [. . . ] Petri Forerii Novae animadversiones [. . .] (Rome: Rev. Camera Apostolica, 1726), 6: "Angeli enim sive boni, sive mali, exactissimam omnium rerum scientiam bene penitus callentes, penitissimasque morborum causas optime conoscentes, materiam sibi subiectam mira facilitate, ac celeritate ad sanitatem suscipiendam disponunt, impedimentis, quae medici, vel ignorant, vel amovere non quent, amotis."

${ }^{40}$ Aquinas, The Summa Theologica, 567 (1.110.4).

${ }^{41}$ Lambertini, Sacra Rituum Congregatio [. . .] Petri Forerii, Responsio theologica, 31: "non posse angelos facere miracula virtute propria, indicant nimirum, quod licet ea possint operari et aliquando operentur virtute divina, numquam tamen ea facere possint sua naturali et ordinaria virtute."

${ }^{42}$ Lambertini, Sacra Rituum Congregatio [. . .] Petri Forerii, Responsio theologica, 33: "ex praemissis nequeunt angeli propria virtute vera miracula facere, sique perpetuus laudabilis stylus huius Sacrae Congregationis e Apostolicae sedis obtinuit approbandi passim ac referendi inter vera miracula sanationes instantaneas."
} 
curable only through medical art and over a long period of time angels would not have been able to cure it perfectly. Therefore, in a cure that was perfect and occurred in a sudden way, it had to be identified as a miracle performed by God, not a cure worked by angels. ${ }^{43}$ The consistorial lawyer may have solved the problem by decreasing the power of angels in the visible world, but this did not solve Lambertini's dilemma. The problem of how to distinguish a recovery that surpasses only the power of corporeal nature from one which surpasses the order of the whole of nature was still present. As we shall see, Lambertini would make up his mind in his famous treatise on beatification and canonization, opting for miracles performed by angels. But it seems that he arrived at this decision gradually, as a manuscript found in his library reveals.

\section{The Notae de miraculis}

Lambertini's function as Promoter of the Faith came to an end in 1728 when he was nominated bishop of Ancona by Pope Benedict XIII. Subsequently, in 1731, he was made archbishop of the diocese of Bologna. It was during his period in Bologna that Lambertini completed his masterwork on beatification and canonization, and at the same time he probably finished writing a short treatise on miracles that was never published.

The unpublished Notae de miraculis (Notes on miracles) is a manuscript of 220 pages that was part of Lambertini's library, which he donated to the university of Bologna during the last years of his pontificate. The manuscript is anonymous, with corrections in the margins of the text and an index, signs that it was a manuscript ready for publication (which never occurred). ${ }^{44}$ Emidio Alessandrini, OFM, has identified Lambertini as the author of the manuscript. According to Alessandrini, Lambertini wrote the treatise when he was young and continued to add passages while he was writing the treatise on the canonization. Eventually, Lambertini decided not to publish it because it no longer matched his own ideas. ${ }^{45}$ Certainly, it is evident that the author finished the manuscript after 1734, since some events that happened in Bologna are mentioned and dated by the same author in the manuscript. These facts are further clues to the authorship of the manuscript, since Lambertini was archbishop of Bologna from 1731 to 1740 . In his introduction to the Notae de miraculis, Alessandrini defines it as a premature and naïve work of Lambertini, especially if compared to his later published work on canonization. ${ }^{46}$ In my opinion, the issue is completely different. First, the Notae de miraculis is not a treatise on canonization but has to be included within the apologetic literature on miracles, of which this work represents one of the

\footnotetext{
${ }^{43}$ Lambertini, Sacra Rituum Congregatio [. . .] Petri Forerii, Responsio theologica, 35: "ita ut si aegritudines tales sint, quae absque praevia medicamentorum dispositione et non nisi longo temporis intervallo curari possent, tunc communiter sentiunt theologi, per simplicem causarum naturalium applicationem, quae celeritate sibi competenti fieri potest ab angelo, sanationem non valere obtineri, et ideo in illo casu indubie censent, quod si sanatio subito sequatur, referri non debeat ad angelos virtute propria operantes, sed ad solum Deum, in cuius tantum potestate est supra ordinem naturae operari."

${ }^{44}$ Notae de miraculis in Biblioteca Universitaria Bologna Ms. 1070 (578 according to the previous collocation). There is a printed version included in Emidio Alessandrini, "Creder tutto . . creder nulla": il Notae de Miraculis: opera inedita del cardinal Prospero Lambertini (Benedetto XIV), sui fenomeni straordinari e magico-superstiziosi, Excerpta ex dissertatione ad Doctoratum in Theologia morali consequendam (Assisi: S. Mariae Angelorum, 1995), 1-156. Cited page numbers refer to this printed copy of the manuscript.

${ }^{45}$ Alessandrini, Creder tutto, LXXXVII-CXIX.

${ }^{46}$ Alessandrini, Creder tutto, CXIV-CXIX.
} 
earlier examples. Second, the Notae de miraculis was written during a period in which Catholicism was threatened by northern natural theology and by the inner diatribes among scholastic theologians. In fact, as I will show in detail, the treatise contains those revisions in the theology of miracle that will also be suggested by Lambertini in his later work on canonization. These novelties were essentially two: the unbreakable nature of natural laws and miracles worked by angels.

Let us begin by examining the structure of the treatise. The manuscript is divided into seven chapters. In the first, "The definition of miracle, notion, and allied points" (De miraculi nomine, notione, et affinibus vocibus), the author introduces the theological concept of miracle. In the second, "Miracles in general; whether God could perform miracles" (De miraculis in genere; an Deus possit facere miracula), he deals with the different types of miracles and with the possibility that even spiritual beings could perform it. The third chapter, "The rules to distinguish between miracles in the controversy made by someone" (De regulis ad discernendum inter miracula in contestationem alicuius doctrinae facta), deals with the rules to distinguish a miracle from an act of magic. In the fourth chapter, "On the incorporeal substances" (De substantiis incorporeis), the author is concerned with the faculties of angels and demons. The fifth chapter, "On magic and its effects in general" (De magia et eius effectibus in genere), is the largest and deals with demonology. In the last two chapters, "On the existence of miracles in Christian religion" (De existentia miraculorum christianae religionis) and "On the quality of miracles in Christian religion" (De qualitate miraculorum christianae religionis), miracles are analyzed in their historical perspective in the Old and New Testament.

I will focus here on two topics that the author of the manuscript develops out of Aquinas's theology: the definition of miracle as an effect against nature (contra naturam) and the role of angels in working miracles.

The concept emphasized in the first chapter of the manuscript is the meaning of "contrary to nature." Lambertini claims that we should conceive the contrary effects as a different way in which things could happen, albeit rarely: a sort of unusual order that belongs to things themselves. The common order of things is switched by the Creator at the moment of the miracle to another order of things. This is a crucial clarification. First, it singles out the author from the other canon lawyers and theologians who declared that the essence of miracle is its contrariness to the natural order. Second, it places the author within the contemporary discussion of miracles in northern Europe. Thus, according to natural theology, it was impossible to admit anything contrary to the order of nature because it would be tantamount to admitting something contrary to God's will. The author is clear: there is no opposite order if it is changed by God's power. ${ }^{47}$ There are two different natural orders: in one, beings are created only by God, and, at the same time, no one could do something supra naturam except God; the other is the order against or beyond what is made by God when he produces a miracle. $^{48}$

\footnotetext{
${ }^{47}$ Alessandrini, Creder tutto, 6.

${ }^{48}$ Lambertini was probably inspired by Augustine's concept of "seminal reasons" (rationes seminales). According to Augustine, at the moment of creation God did not only implant in things those semina that let them grow and generate similar things; he also implanted semina that could produce something different from ordinary growth. The semina were unknown to human beings; only angels, demons, and, of course, God knew where they were and how to use them. This theory is reported in a frequently quoted passage of The Literal Meaning of Genesis, where Augustine explains the ordinary and extraordinary generation of things. See Augustine, The Literal Meaning of Genesis, vol. 1, trans. John Hammond Taylor (New York: Paulist, 1982), 93 (9.17.32).
} 
In the second chapter of the manuscript, the author openly denies Spinoza's thesis on the impossibility of miracles, since miracle should produce something against the law of God that coincides with the order of nature. According to Spinoza, God was eternal and immutable, thus he cannot go against himself. The author again rebuts, saying: "They say that they [miracles] happen against nature, because they are not in the way they would be in the ordinary course of nature; which is not true that God changes nature, that God pervades the course of nature, this is absolutely not true, since somehow they are natural things, since they happen by the will of Him, which is the very nature of all things." ${ }^{49} \mathrm{He}$ continues: "The miracle does not destroy the laws of nature, indeed it is natural law, in order to which something could occur in a marvelous way, though it is not law that appears in a more customary way; and this is because the effects of that law are rare. God's will is natural law, it is both the law of nature and the will of God, in the way that this or that happens over time in an admirable way." 50

In these two passages, the author is saying that nature coincides with God's will, avoiding any mention of the separation of the natural and the supernatural. The influence of Augustine's theology is again clear. ${ }^{51}$

The second issue discussed by the author is whether created beings can produce miracles. Like Aquinas and earlier canonists, he believes that angels can be used by God as instruments to perform miracles. He agrees with Aquinas in the distinction of three kinds of actions that a spiritual being can do as miracle worker: preaching, preparing matter for miracles, and co-acting with God. This faculty is a gift, meaning that they cannot perform miracles every time they want: "They receive from God the virtues to accomplish miracles, but as the way of the imperfect forms, which does not last except at the presence of the principal agent." ${ }^{\text {"2 }}$ It occurs in the same way with prophets, continues the author, who cannot prophesy whenever they want but only when the spirit touches their hearts and they receive the gift of foresight. ${ }^{53}$ God binds the motion of corporeal things to the will of spiritual beings in order that the created things, mostly corporeal, obey it even if the effect goes against the order of nature. $^{54}$

\footnotetext{
${ }^{49}$ Alessandrini, Creder tutto, 13-14: "Dicuntur autem fieri contra naturam, quia non sunt eiusmodi, quae sint secundum ordinarium cursum naturae; unde non est verum, Deum naturam mutare, Deum naturae cursum pervertere, non est hoc absolute verum, siquidem portenta ipsa quodammodo naturalia sunt, cum fiant per eius voluntatem, quae est ipsa omnium rerum natura; quia vero non sunt iuxta leges naturae, et consuetas, hinc dicuntur esse contra naturam."

${ }^{50}$ Alessandrini, Creder tutto, 14-15: "Miraculum naturae leges non destruit, immo est naturalis lex, ut hoc, vel illud admirabile sequator, quamquam non sit lex, quae consueta magis appareat; et ideo hoc est, quia rara sunt talis legis effecta. Voluntas Dei est lex naturae, et lex naturae, e t voluntas Dei est, ut hoc, vel illud admirabile in tempore sequator."

${ }^{51}$ Another purpose displayed by seminal reasons (mentioned in $\mathrm{n} 48$ ) was in fact to include the extraordinary in the ordinary course of nature. Since every occurrence, including the exceptions, have already been implanted in things, nothing could have happened against the order of nature. All exceptions are already to be expected as causal reasons previously included in things by God. See Augustine, The Literal Meaning of Genesis, 6.14.25.

${ }^{52}$ Alessandrini, Creder tutto, 17: "habent a Deo virtutem in miraculis cooperandi, sed per modum formarum imperfectarum, quae non permanent, nisi ad presentiam agentis principalis, ut lumen in aere motus in instrumento etc."

${ }^{53}$ Alessandrini, Creder tutto, 17.

${ }^{54}$ Alessandrini, Creder tutto, 17-18.
} 
Thus far, the position held by the author of our manuscript does not diverge radically from previous theological beliefs. The step forward consists in claiming that spiritual beings are not just the moral causes of miracle. They do not just wish for a miracle (non solum imperative) but bring it about (sed etiam operative), cooperating with God:

But in a miracle which is said to be done by a spiritual substance, the spiritual substance itself is operating. For [the spiritual substance] wills the miracle and, by this very act of willing, it brings about the miracle because it was thus pleasing to God that such a power be bound to its will. But this way of operating is almost of the same sort by which God himself works, except for the fact that [the work of the spiritual substance] is distinct with regard to its limitation and in its dependence. ${ }^{55}$

In conclusion, only God can perform miracles according to a natural virtue, and sometimes he shares the faculty of producing miracles with natural causes according to their capacity and the order of divine providence. ${ }^{56}$

Regarding the issue of how angels could act on corporeal beings, the author follows Aquinas. The first question is: Do angels have a body? Put in a more metaphysical way, this becomes: Are angels corporeal or incorporeal in substance? He does not diverge from Aquinas's belief in the power and faculty of angels. They are limited in corporeal nature since they are spiritual; they cannot do all the things a corporeal being can do. However, they can act as a soul acts in the human body-and even better, since their knowledge of the laws of nature is higher than the knowledge of corporeal beings. As a result, they can naturally perform wonders that marvel the observer. However, these are not miracles since they are effects that surpass only the order of things known by the observer rather than the order itself. Finally, demons cannot perform any miracles because God prevents them. ${ }^{57}$

The aim of the author of the manuscript, and Lambertini's in his later published work, was to adjust the theory of miracle to the challenges of the period. The main topics that I examined in the manuscript are found in Lambertini's later published treatise on beatification and canonization, giving a high degree of certainty to the authorship of the manuscript. We do not really know the reasons why the manuscript was never published. As the main innovative points will reappear in the following treatise on canonization, that probably was not a reason. It is not a premature or naive treatise, as Alessandrini sustained. Rather, if it was really written by Lambertini, it proves that his intentions were clear from the beginning. They are clear points that respond to the main attacks against the existence of miracles made by some natural philosophers of northern Europe. The Notae de miraculis is an early example of apologetic treatise on miracles, a kind of literature that flourished in Italy during the eighteenth century. ${ }^{58}$

\footnotetext{
${ }^{55}$ Alessandrini, Creder tutto, 18: "in miraculo autem, quod a spirituali substantia fieri dicitur, ipsa spiritualis substantia operatur; vult enim miraculum, et hoc ipso actu volendi miraculum efficit, quia Deo sic placuit, ut ipsius voluntati esset alligata talis potestas; hic autem modus operandi eiusmodi fere est, quo Deus ipse operetur: nisi quod discrepat in limitatione, et in dependentia."

${ }^{56}$ Alessandrini, Creder tutto, 19.

${ }^{57}$ Alessandrini, Creder tutto, 47-58.

${ }^{58}$ For instance, see Liberato Fassoni, De miraculis adversus Benedictum Spinozam (Rome: Ex Typographia Joannis Zempel, 1755); and Andrea Spagni, De miraculis (Rome: Typis Arcangeli Casaletti, 1777).
} 


\section{The De servorum Dei beatificatione et beatorum canonizatione}

Between 1734 and 1738, when he was archbishop of Bologna, Lambertini published a treatise on the beatification and canonization process entitled De servorum Dei beatificatione et beatorum canonizatione (The beatification of the servants of God and the canonization of the blessed). After a few years, in 1743, a second and revised edition was published in Padua, and a third revised edition was published between 1747 and 1751 in Rome under the supervision of Emanuele Azevedo. ${ }^{59}$ Despite there being numerous other authors of treatises on canonizations, Lambertini made much use of the new ideas developed in iatromechanics and iatrochemistry, revealing (besides a great knowledge) an awareness of the importance of medicine in miracle investigations. ${ }^{60}$

I am going to focus on the theological and philosophical issues, especially Lambertini's denial that there was any clash between the laws of nature and the definition of miracle as well as his argument for miracles performed by angels. These two points, as we have learned in the previous section, are brought forward by Lambertini to counteract the denial of the existence of miracles claimed by some northern European philosophers, such as Spinoza and some Deists. ${ }^{61}$

In the treatises on canonization prior to that of Lambertini, the possibility that angels can perform miracles is always explicitly denied, and the fact that miracles are events contrary to the natural order is always made explicit. They argue that some diseases can be healed by angels in an impossible way for medical art and the virtues of nature, but it is not for this that those healings can be called miracles. The only exception is Bordoni: as he does not distinguish an ontological difference between nature and supernature, he does not provide an equal definition of miracles as an event against nature. $^{62}$

Since Lambertini made some relevant changes between the Bolognese and the Paduan edition, I will usually refer to the second edition. However, I will report the references of both editions whenever they do not match. The De servorum Dei beatificatione is composed of four books, which cover all the issues of beatification and canonization procedure. The first part of the fourth book deals with miracles. This part can, in turn, be divided into an initial part concerned with miracles in general: their classification, cause, ends, task, etc.; and a following part, in which specific (mostly healing) miracles are treated.

\footnotetext{
${ }^{59}$ Prospero Lambertini, De servorum Dei Beatificatione et beatorum canonizatione (Bononia: Formis Longhi Excusoris Archiepiscopalis, 1734-1738); Prospero Lambertini, De servorum Dei Beatificatione et beatorum canonizatione (Padua: Typis Seminarii apud Joannem Manfrè, 1743); and Prospero Lambertini, De servorum Dei Beatificatione et beatorum canonizatione (Rome: Excudebant Nicolaus et Marcus Palearini, 1749-1751). See Pietro Amato Frutaz, "Le principali edizioni e sinossi del De servorum Dei beatificatione et beatorum canonizatione di Benedetto XIV. Saggio per una bio-bibliografia critica," in Atti del convegno di studi storici su Benedetto 14, ed. Errebi (Falconara Marittima: Errebi, 1982), 27-90.

${ }^{60}$ See Gianna Pomata, "The Devil's Advocate among the Physicians: What Prospero Lambertini Learned from Medical Sources," in Benedict XIV and the Enlightenment: Art, Science, and Spirituality, ed. Rebecca Messbarger, John Gavitt Philip, and Christopher M. S. Johns Toronto: University of Toronto Press, 2016), 121-150.

${ }^{61}$ Burns, The Great Debate on Miracles.

${ }^{62}$ See Rocca, De canonizatione sanctorum, 17-21, 43-45, 55-56; Contelori, Tractatus et praxis de canonizatione sanctorum, 175-177, 185; De Matta, Novissimus, 170; Brancati, “De miraculis," 497-500, 549, 579-580; Bordoni, De miraculis, 5-7 (contained in his Opus posthumum); and Matteucci, Practica theologico-canonica, 143-144, 163.
} 
Right from the beginning of the fourth book, Lambertini points out that the created world has to be understood as twofold: one is the natural and visible world, the other is the supernatural world in which everything is a miracle. ${ }^{63}$ Lambertini considers the natural and the supernatural as belonging to the same created world. He probably alludes to the Jesuit Juan Martinez de Ripalda's (1594-1668) concept of created supernatural (substantia supernaturalis creata), conceived to defend the gratuity of the supernatural from the Pelagians' attacks, such as the Baian controversy. ${ }^{64}$ In the following sentence, he makes clear that he will not deal with those miracles that belong to another order of things, established by God, which is known by us only through faith, such as God's Incarnation, the conception of Mary, Jesus's Resurrection, the introduction of the Holy Spirit, the working of the sacraments, and the glorification of the body. ${ }^{65}$ These are considered miracles of a superior order. By contrast, Lambertini continues, "in this treatise miracles are restricted to the natural and inferior order." 66 In the subsequent section, he explains the relation that interposes between these two orders: one has to be above the other.

If we compare Aquinas's definition of miracles with Lambertini's, we will notice some differences. In The Power of God, Aquinas opens the issue of miracle with the question of whether God could do anything beyond natural causes (praeter causas naturales), against nature (contra naturam), or against the order of nature (contra cursum naturae). ${ }^{67} \mathrm{He}$ replies by quoting a passage from Aristotle's Metaphysics (bk. 8, chap. 5), to which Aquinas adds two crucial words: "secundum naturam" (according to nature). This distinction will become an axiom for sixteenth- and seventeenth-century definitions of miracle as an event contrary to the course of nature: "There is no return from privation to habit according to nature." ${ }^{\prime 68} \mathrm{He}$ rebuts three different schools and philosophers who believe that nothing can happen contrary to the course of nature: firstly, the pre-Socratics, who think that corporeal things do not derive their existence from any higher cause; secondly, Avicenna, who says that God is the cause of all things by means of his intellect; and thirdly, the Neoplatonists, who state that God produces things by natural necessity, hence confined within the order of nature. For each of those philosophical traditions, it is inconceivable that something could occur contrary to the order of nature since God belongs to the same natural order. On this topic, Aquinas's cosmology represents an absolute novelty. He claims that the pre-Socratics are wrong because they do not believe in a supreme being; Avicenna is wrong because he believes that God created the universe through divine intellect; and finally, the Neoplatonists are wrong because they believe that all that belonged to God is ruled by necessity. On the

\footnotetext{
${ }^{63}$ Lambertini, De servorum Dei Beatificatione (1743), 2 (4.1.1): "Duplex est ordo totius naturae creatae a Deo institutus; alter naturalis, quo visibilis hic mundus regitur, e gubernatur, alter supernaturalis, qui pertinet ad Gratiam, et Gloriam Sanctorum."

${ }^{64}$ See Eduardo Vadillo Romero, La controversia de la sustancia sobrenatural en los teólogos dominicos españoles del siglo XVII, una reflexión fundamental sobre la gracia creada (Toledo: Estudio teológico San Ildefonso, 2001); and Henri de Lubac, Augustinianism and Modern Theology, trans. Lancelot Sheppard (London: Geoffrey Chapman, 1969), 262.

${ }^{65}$ Lambertini, De servorum Dei Beatificatione (1743), 2 (4.1.1).

${ }^{66}$ Lambertini, De servorum Dei Beatificatione (1743), 2 (4.1.2): "Sermo ergo noster ad ordinis naturalis, et sic inferioris miracula restringitur."

${ }^{67}$ Thomas Aquinas, The Power of God, trans. Richard J. Regan (Oxford: Oxford University Press, 2012), 161-164 (q. 6, art. 1).

${ }^{68}$ Aquinas, The Power of God, 162 (sed contra): "A privatione in habitum non potest fieri regressus secundum naturam."
} 
contrary, Aquinas claims that there is no intermediary between God and nature and that God does not act by natural necessity. Consequently, God can act against nature because nature is no longer related to him after the Creation. God can act against nature because the order of things is twofold: one is ruled by necessity through secondary causes, and the other is ruled by God's will. ${ }^{69}$

Conversely, in the early sections, Lambertini shows how the supernatural order is not contrary to the order of created nature but rather is part of that order that is made of ordinary and extraordinary things. The integrity of created nature is preserved. Lambertini did not emphasize the contrariness of miracles but their "aboveness" with respect to the course of nature. On the contrary, Aquinas never spoke of a supernatural order but only of a supernatural agency. The concept of a created supernatural allowed Lambertini to speak of a supernatural order well defined from the natural-one in which God was not necessary included. In fact, Lambertini introduces the term ordo supernaturalis for the first time in a canonization treatise. Previous canonists speak of supernatural action or supernatural effect but never of an order.

The second topic which links Lambertini's De servorum Dei beatificatione with the anonymous manuscript analyzed in the previous section is the role assigned to angels. He writes, "You will ask, whether it is necessary for a miracle to consist of something which exceeds the forces and faculty of invisible and incorporeal as much as visible and corporeal nature, since it is the same to ask if something which exceeds only the forces of visible and corporeal nature, and is arduous, unusual and causes wonder, can be identified as a miracle even if it does not exceed invisible and incorporeal nature, which are angels." 70

Beginning in the first chapter, Lambertini queries whether Aquinas's definition of a miracle as something exceeding the whole order of nature should be intended as the only definition given by him. In fact, Aquinas in the Summa Theologica briefly mentions a loose definition of miracle that surpasses only nature known to man (quoad nos). ${ }^{71}$ The definition of a miracle as something that exceeds corporeal and visible nature, in the sense of nature known to man, would, as direct consequence, have to admit that angels and demons could perform miracles, contradicting what Aquinas said in the previous treatise The Power of God. ${ }^{72}$ It was probably just an attempt made by Aquinas to keep a door open to Augustine's definition, with which, despite fundamental differences, he always tries to avoid dispute by bringing Augustine to his side.

Lambertini, for its part, refers to Aquinas's ambivalent definition in order to find theological footholds to give legitimacy to his proposal. "It seems one can infer that unusual and marvelous effects which exceeds forces and faculty of created nature, visible and corporeal which is known by us, are miracles even if they do not exceed the forces and faculty of created nature invisible and incorporeal." ${ }^{, 73}$ And Lambertini calls miracles

\footnotetext{
${ }^{69}$ Aquinas, The Power of God, 164-165.

${ }^{70}$ Lambertini, De servorum Dei Beatificatione (1743), 9 (4.1.14); and Lambertini, De servorum Dei beatificatione (1738), 11 (4.1.12): "Quaeres, an ad constituendum miraculum necesse sit, ut aliquid excedat vires et facultatem naturae tum invisibilis et incorporeae, tum visibilis et corporaee, quod est idem ac quaerere an si aliquid excedat tantum vires naturae visibilis et corporeae, et sit arduum et insolitum et admirandum miraculum dici possit, etiamsi non excedat vires naturae invisibilis et incorporeae, hoc est angeli."

${ }^{71}$ Thomas Aquinas, The Summa Theologica, 1.110.4 ad secundum.

${ }^{72}$ See Aquinas, The Power of God, 170 (q. 6, art.3).

${ }^{73}$ Lambertini, De servorum Dei Beatificatione (1743), 9 (4.1.14); and Lambertini, De servorum Dei beatificatione (1738), 12 (4.1.12) "Ex his autem inferri posse videtur, quod effecta insolita, et admiranda, quae
} 
of this type miracula minora. According to him, angels could perform miracles propria virtute, under God's will. ${ }^{74}$

What Aquinas considered an improper miracle became a proper miracle according to Lambertini. There are no improper miracles in Lambertini's thought, in the sense that he does not have to modify the definition of miracle in order to accept the minor miracles operated by angels.

Lambertini claims that this type of miracle has already been adopted by previous eminent scholars. In chronological order, we find: Francisco Suarez's De angelis (1620); Silvestro Pietrasanta's Thaumasia vera religionis (1643-1655), in which miracles do not surpass the power and potency of invisible and incorporeal nature; Matteo Magnani's Dissertatione de lacrimis imaginis sancta Mariae de Gratiis Pinnae Billorum (1652), in which miracles are divided among those that surpass the force of the whole nature and those that exceed only the force of corporeal nature; the abbot Claude Frainçois Houtteville's La vérité de la religion chrétienne prouvée par le faits (1722); and Samuel Christian Holmann's Commentatio philosophica de miraculis (1727), in which some miracles do not surpass the forces of the whole created nature. Finally, Lambertini appeals to the authority of Augustine, whose definition of miracle was exclusively based on the wonder produced among the witnesses of something that they could not explain. Lambertini proposes the identification of two different types of miracles: higher miracles (miracula maiora), which exceed the whole of created nature, and lower miracles (miracula minora), which exceed only corporeal and visible nature. $^{75}$

With the exception of Suarez, the authors mentioned above did not really argue for a new idea of miracle. Instead, they just took it for granted. By contrast, Lambertini was conscious of the importance of that novelty. According to him, the problem arose because it was impossible to distinguish between an event surpassing the preternatural, which is angelic and demonic in nature, from one merely surpassing corporeal and visible nature. "On the one hand, it seems necessary that in the assessment of miracles only those which exceed the forces and faculty of all created nature are allowed. On the other hand, it is difficult to know and distinguish whether a miracle, which has been proposed in that assessment to be examined, would exceed the forces of invisible and incorporeal good angels." 76 The importance of this passage is crucial. Lambertini is saying that the boundaries between the preternatural and the supernatural are blurred. Theoretically, continues Lambertini, a sudden recovery of health or the conversion of one substance into another (such as the conversion of water into wine or the multiplication of the loaves and the fishes) can occur in a twofold way: they can either exceed both corporeal and visible nature as well as incorporeal and invisible nature, or they can exceed just visible and corporeal nature. If new matter has been produced, modified, or multiplied, or if a substance has been converted into another, then it surpasses the whole of created nature. By contrast, if the particles of a fire are carried through the

excedunt vires et facultatem naturae creatae visibilis et corporeae nobis notae, miracula sunt, etsi non excedant vires e facultatem naturae creatae invisibilis et incorporeae."

${ }^{74}$ Lambertini, De servorum Dei Beatificatione (1743), 14 (4.2.7).

${ }^{75}$ Lambertini, De servorum Dei Beatificatione (1743), 11 (4.1.17); and Lambertini, De servorum Dei beatificatione (1738), 14 (4.1.15).

${ }^{76}$ Lambertini, De servorum Dei Beatificatione (1743), 56 (4.6.6): "Ex una etenim parte necessarium esse videretur, ut in iudicio adeo gravi non admitterentur nisi miracula , quae excedunt vires et facultatem totius naturae creatae; ex alia vero parte difficile admodum est, scire posse, et posse dignoscere, an miraculum, quod proponitur in hoc iudicio examinandum, vires excedat naturae invisibilis et incorporeae angeli boni." 
air suddenly from one place to another, collected together, and thrown suddenly toward the ground, and if something suddenly has been taken away and at the same time substituted with something else by an invisible creature, these events do not exceed the faculties of angels. ${ }^{77}$

Lambertini realized that phenomena that did not surpass the whole of created nature, but just corporeal and visible nature, had been approved as miracles in numerous beatification and canonization trials. According to Lambertini, it was not possible to distinguish in a miracle whether it exceeded incorporeal and invisible nature, which was the whole created nature. Theoretically, a recovery from a fever could exceed the whole power of created nature or just the visible and corporeal. The former would have happened without the employment of any secondary causes, as a pure act of God's will. The latter would have happened through secondary causes; in the case of fever, bad humors would have been expelled suddenly and without any expectation in a way that naturally would have been impossible. However, since Lambertini had long experience as Promoter of the Faith, he was conscious that this distinction, though theoretically correct, was impossible in practice. There was no means of distinguishing between an angelic performance, which simply went beyond corporeal and visible nature, from a performance exceeding the whole power of nature:

Consequently, if only miracles which surpass the forces of all created nature have to be admitted in beatification and canonization assessment, we have to exclude those which were examined above, and those similar to them, because we cannot distinguish if they occurred in one or another way; and it would occur that only those miracles which consisted of the penetration of bodies, replication of them, secret revelations of the human heart, prophecies of future events which depend on human freedom and resurrections and almost all recoveries from a disease, would not be admitted as miracles in canonization assessment. ${ }^{78}$

This means that if one did not accept that angels could perform miracles, it risked delegitimizing the entire enquiry into miracles.

Lambertini refers to the ancient fathers of the church to legitimize his claim. He stresses the fact that Augustine focused the definition of miracle on the witnesses' lack of knowledge. Furthermore, he quotes Aquinas, picking up those passages in which the author explained the non-canonical type of miracle. Lambertini cleverly shows how both authors assumed the possibility of miracles that depended on the knowledge not just of the witnesses but of all human beings. This was the knowledge that corresponded to corporeal and visible nature. In addition of the ancient fathers of the church, Lambertini quotes Francisco Suarez, who was a Jesuit. From the start, the Jesuits has chosen Aquinas's theology in their war against heresy. However, since their subscription to Aquinas's theology was not so strict as it was for the

\footnotetext{
${ }^{77}$ Lambertini, De servorum Dei Beatificatione (1743), 56-57 (4.6.7).

${ }^{78}$ Lambertini, De servorum Dei Beatificatione (1743), 57 (4.6.7): "Quocirca, si in iudicio beatificationis et canonizationis miracula tantum supra vires cuiusque naturae creatae admitti debent, ab eo excludenda erunt, quae supra recensimus, et illis similia, cum scire non possimus, utrum uno an alio modo acciderint; et tantum locus erit miraculis penetrationis corporum, replicationis ipsorum, revelationis secretorum cordium humanorum, praedictionis futurorum eventuum ab humana libertate pendentium, et suscitationis mortuorum, et fere autem nullae sanationes a morbis poterunt in iudicio canonizationis admitti tamquam miracula."
} 
Dominicans of the Salamanca school-the real defenders of Aquinas-there was frequently friction between the two orders. One of those disagreements concerned the extension of the miraculous to the work of angels.

In the 1738 edition of De servorum Dei beatificatione, Lambertini refers to some salmanticenses, faithful followers of Aquinas, who believed that the order of miracles had to be based in the way the effect happens, not in the effect itself. ${ }^{79}$ The order of nature was still functioning according to Aristotelian hylomorphism; consequently, all that was produced through potency and act could not be considered a miracle. This theory faithfully reflected Aquinas's concept of miracle, since it leaves no room for miracles performed within the order of created nature.

One of the members of Salamanca school was the Dominican Francisco de Araujo (1580-1664). Born in Spain in 1580, Araujo joined the Dominicans in Salamanca, where he also studied and taught philosophy. In his treatise Decisiones morales (1664), quoted by Lambertini, he denied the possibility of miracles that exceeded only nature known by us. Araujo claimed that this was just a belief of common people who thought that some marvelous and rare things were miraculous because they surpassed their own knowledge and industry. These included exorcisms, the sweet smell coming from a corpse, frequent ecstasy, lengthy fastings, cures in which the person who was invoked appeared, and the use of images, little rocks, and part of the clothes of a person to cure someone by contact. According to Araujo, all these works could be easily done by angels, demons, or the imagination of the one suffering. ${ }^{80}$

Araujo was a strict defender of Aquinas's definition of miracle and was aware of the fact that the difference between what was believed by common people and what was a proper miracle was an ontological issue. Angels and demons, he wrote, "cannot by themselves or through magicians neither reverse the order of the universe, nor change God's law, nor remove an entire object from its place; nor they can annihilate something or produce something out of nothing, since creation and annihilation are peculiar works of divine omnipotence." 81 The only miracle accepted by Araujo was that made ex nihilo, which was God's privilege. He remarked that claiming that angels could also perform miracles was superstitious since, according to Aquinas, "superstition is to worship something that you do not have to, or in the way that you should not do." ${ }^{82}$ According to Araujo, there were two different realms: the supernatural, which was represented by the divine action, and created nature, which included angels, demons, and humans and which had its power regulated by Aristotelian hylomorphism. He writes, "But neither by themselves [angels and demons] or their magicians, can they suddenly introduce the substantial form into matter, except by means appropriate to the previous dispositions and proportionate to that form which are introduced by applying

\footnotetext{
${ }^{79}$ Lambertini, De servorum Dei Beatificatione (1743), 3-4 (4.1.4). The salmanticenses was one of the three Carmelitane's collective enterprises that systematized the Thomistic corpus in a non-commentary form following Suarez's effort. The complutenses covered the philosophical issues (1624-1628), the first salmanticenses dealt with dogmatic theology (1631-1704), and the second salmanticenses was concerned with moral theology (1665-1707). See Pereira, Suarez, 60.

${ }^{80}$ Francisco de Araujo, Variae et selectae decisiones morales ad statum ecclesiasticum et civilem pertinentes (Lyon: Philippi Borde, Laurentij Arnaud, Petri Borde, and Guill. Barbier, 1664), 163 (3.23.83).

${ }^{81}$ De Araujo, Variae et selectae decisiones morales, 166 (3.23.102): “[angeli et demones] non possunt per se aut suos magos ordinem universi invertere, neque legem ordinariam praefixam a Deo mutare, neque integrum elementum de suo loco exturbare; neque aliquam rem annihilare aut ex nihilo producere, quia creatio et annihilatio sunt prorprium opus divinae omnipotentiae."

${ }^{82}$ The phrase is quoted by Araujo in Variae et selectae decisiones morales, 163 (3.23.87).
} 
active to passive. Hence, they cannot produce even one of the three classes of miracles, except in a fake and apparent way which we call illusory effects." ${ }^{\prime 3}$

Araujo was a straight Thomist who did not accept the novelties coming from the Society of Jesus. As it happened with Ripalda's concept of created supernatural, it would certainly have happened with Lambertini's loose definition of miracle, too.

\section{Conclusion}

Amos Funkenstein, followed by Louise Dupré and Brad S. Gregory, identified in Duns Scotus and Ockham the origins of the changing relation of God and nature. ${ }^{84}$ The shift from an analogical to an univocal relationship between the natural and the divine caused, they argued, a process of anthropomorphization of God, which ended with the metaphor of God as the great artisan and the watchmaker. The shift described in this paper is different albeit similar. From the standpoint of the history of the concept of miracle, it is not God who had been objectified but his agency: the supernatural, which became a concrete order of things opposite to the natural order. Everything began with the separation of the divine agency from the natural one in the late Middle Ages as a consequence of the Scholastic effort to combine Aristotelianism and Christian theology. Whereas Augustine developed the concept of semina rationales to avoid any contradiction between the action of God through miracles and the order of nature, Aquinas borrowed the Aristotelian concept of secondary causes, which guaranteed a self-sufficient nature disjointed from the divine order. The description of the natural and the supernatural as opposite terms was then stressed by Catholic theologians to preserve the gratuity of the supernatural and to defend it from Pelagian or semi-Pelagian attacks. Lambertini adopted the view that the natural and the supernatural were oppositional, emphasizing the aboveness of the latter relative to the former rather than merely their contrariness.

Lambertini represents a precise attempt to reform the theology and philosophy of miracle from within. I identified two features of his proposal: the idea of miracle as an event not contrary to natural laws and the capacity of angels to perform miracles. Lambertini's claiming of the miracle as a phenomenon not contrary to the laws of nature is a response to Spinoza, who refused the possibility of miracles because they should be contrary to God's will, since according to him God should coincide with natural laws. This is also a response to the Deists' refutation of any irrational explanation of the supernatural. On the other hand, the claim that miracles might be performed by angels is due to Lambertini's acknowledgement that it is no longer possible to distinguish whether something is exceeding the boundaries of the whole of created nature from something exceeding the boundaries of visible and corporeal nature. Consequently, Lambertini's declaration that angels could perform miracles was not

\footnotetext{
${ }^{83}$ De Araujo, Variae et selectae decisiones morales, 166 (3.23.102): "Sed neque per se aut suos magos possunt formam substantialem immediate in materiam introducere, nisi mediis dispositionibus praeviis aptis et proportionatis tali formae, quas si introducant applicando activa passivis, poterunt et ipsam formam introducere. Unde neque aliquod ex tribus classibus recensitis miraculum vere efficere possunt, nisi tantum ficte et secundum apparentiam quos praestigiosos effectus vocamus."

${ }^{84}$ Amos Funkenstein, Theology and the Scientific Imagination: From the Middle Ages to the Seventeenth Century (Princeton: Princeton University Press, 1986); Louise Dupré, Passage to Modernity: An Essay in Hermeneutics of Nature and Culture (New Haven, Conn.: Yale University Press, 1993); and Brad S. Gregory, The Unintended Reformation: How a Religious Revolution Secularized Society (Cambridge, Mass.: Belknap, 2012).
} 
an innovation or a new proposal that came out from his mind but was the awareness of a discrepancy between the current definition of miracle and the factual miracles as examined in canonization trials. It was Lambertini's effort to adjust theory to practice.

Regarding the historical figure of Lambertini, recent historiography has discussed whether he should be considered an Enlightenment man. In my opinion, if being a Catholic enlightener means "(a) to use the newest achievements of philosophy and science to defend the essential dogmas of Catholic Christianity by explaining them in a new language, and (b) to reconcile Catholicism with modern culture," then Lambertini behaved like a Catholic enlightener. ${ }^{85}$ He developed a new classification of miracle that would have made the assessment of miracles more precise and less exposed to the attacks of detractors-a classification, moreover, that did not contradict Catholic tradition. Lambertini felt the arduous task of defending Catholicism from the appearance and growth of atheism. An extract of Lambertini's letter to the cardinal Pierre Guérin De Tencin (1680-1758) confirms this concern: "It would be time to finish these competitions and that Catholic theologians would write against materialists, atheists, deists who are trying to eradicate Our Holy Religion from its grounds." ${ }^{\prime \prime 6}$

Nevertheless, we can say that he also behaved like a canon lawyer used to behave during the whole seventeenth and the beginning of the eighteenth century, struggling to find different ways for a more efficient method of miracle authentication.

Finally, through the examination of Lambertini's reconsideration of the concept of miracles, we had the chance to recognize a deeper cultural change between the relationship of God and nature-one in which the boundaries between the corporeal nature and the works of angels became much more visible while those between God and the whole of the created nature became increasingly less visible. We can appreciate this profound change in point of view in the words of the priest and philosopher Antonio Conti (1677-1749) when he described the birth of a new sense of the world in this emblematic way: "I began clearly aware that to begin reasoning from the senses was very different than beginning from God." 87

Alessandro Laverda is a postdoctoral researcher at the University of Naples Federico II. He is the author of the recent book La nascita del sovrannaturale: Storia di una separazione tra Dio e natura (Mimesis, 2021).

\footnotetext{
${ }^{85}$ Ulrich L. Lehner, The Catholic Enlightenment: The Forgotten History of a Global Movement (Oxford: Oxford University Press, 2016), 7.

${ }^{86}$ Prospero Lambertini, “Lettera al card. De Tencin, Rome 3rd May 1752," in Le lettere di Benedetto XIV al card. de Tencin. Dai testi originali, vol. 2, ed. Emilia Morelli (Rome: Storia e letteratura, 1965), 473: "Sarebbe ormai tempo che finissero queste gare, e che i teologi cattolici scrivessero contro i materialisti, gli ateisti, i deisti, che tirano a svellere la Santa Nostra Religione da' suoi fondamenti."

${ }^{87}$ Antonio Conti, Prose e poesie, vol. 2 (Venice: Giambatista Pasquali, 1756), 4: "Ben mi accorsi che il cominciar da' sensi a filosofare era diversissimo dal cominciar da Dio."
}

Cite this article: Laverda, Alessandro. "Revising the Supernatural: Prospero Lambertini's Reconsideration of the Concept of Miracle." Church History 90, no. 1 (March 2021): 45-67. https://doi.org/10.1017/ S000964072100072X. 